\title{
Chapter 2 \\ Knowledge Society, Educational Attainment, and the Unequal City: A Sociospatial Perspective
}

\author{
Ulrike Gerhard, Michael Hoelscher, and Editha Marquardt
}

Modern society is increasingly described as a "knowledge society" (Stehr \& Meja, 1984), or, from a more limited perspective, as a "knowledge economy" (Sörlin \& Vessuri, 2007). Following from that, education, as a process of facilitating learning and knowledge acquisition (see Fröhlich \& Gerhard, 2017), has gained in importance for the individual as well as for society, since educational achievements are strongly influencing job opportunities and the ability to partake in public, social, and political life. Education, however, is acquired in a certain socioenvironmental setting that has a decisive impact on educational opportunities and achievements. In the case of formal knowledge, organizations such as kindergartens, schools, universities, and other institutions of higher education play a crucial role because they are understood as key institutions in knowledge-driven societies.

In this paper, we argue that the socioenvironmental setting influencing education is strongly related to the urban context. It is the city itself, with special atmospheres of learning and education, a manifold distribution of and access to educational institutions, the existence of different neighborhoods and specialized city quarters, as well as a diverse range of protagonists in the field of informal learning that creates an educational environment highly relevant for knowledge production. In the general discourse urbanity and the urban milieu are often regarded as seedbeds for the production of creative ideas, smart development, and knowledge invention. Even more, the condensed presence of educational organizations, creative industries, and research-oriented industries is thought to stimulate prosperous urban development. Researchers, most dazzlingly Florida (2002), but also more evidence-based scholars (e.g., Gabe, Abel, Ross, \& Stolarick, 2012; van Winden, van den Berg, \& Pol, 2007),

\footnotetext{
U. Gerhard $(\square)$

Department of Geography, Heidelberg University, Heidelberg, Germany

e-mail: u.gerhard@uni-heidelberg.de
}

\section{Hoelscher · E. Marquardt}

Chair in Higher Education and Research Management, German University of Administrative

Sciences Speyer, Speyer, Germany 
mainly portray this reciprocal relationship between knowledge society, socioenvironmental settings, and education in a positive light. They accept the city's knowledge sector as the main engine for growth strategies that lure people, companies, and investments. City policymakers deliberately try to foster this relationship by supporting knowledge-intensive industries, hosting educational and research institutions, and thereby attracting creative knowledge workers.

However, the picture might not be as positive as is often claimed. In accordance with several other studies, we contend that urban stakeholders and researchers have often tended to overstate the economic impact of knowledge institutions (Addie, Keil, \& Olds, 2015; Siegfried, Sanderson, \& McHenry, 2007). Although it is true that knowledge institutions create employment opportunities, these jobs, as well as the related economic effects, do not necessarily benefit the whole urban population. Furthermore, the appraisal of the knowledge society, with its ubiquitous disposition of knowledge that has led to an open, more egalitarian society, increasingly appears to be a myth: Knowledge and education are not available for everybody in the same way. Knowledge-based urban development, and the concept of a knowledge society more broadly, often create new inequalities. Even Florida, once the main proponent of the "creative city," now admits that these creative urban environments are also the most unequal ones (Florida, 2017).

In this paper, we combine a sociological and urban geographic perspective to try to disentangle the assumed positive connotation of the tripartite relationship between education, knowledge-based urban development, and individual well-being. What are the consequences of knowledge-induced urban growth, especially regarding social equity? How do cities with a strong knowledge sector develop in sociospatial terms? What can we learn from an interdisciplinary analysis of the educational system in the city? In order to answer these questions, we connect the debates on urban (re)development, knowledge society, and education by following three conceptual steps. To begin, we outline the concept of knowledge-based development by looking at the involvement of knowledge institutions in urban development from a broader perspective, based on a literature review in the first section of the paper. We then consider the possible disadvantages of the acclaimed growth of knowledge cities in the second section. As a third step, we analyze the role educational systems play in producing such inequalities. For this purpose, we analyze the spatial production of educational success in the city from a cross-disciplinary perspective. We argue that educational institutions play a major role in the marketization of urban space, and, thus, contribute to the increasing urban inequalities inherent to knowledge societies. Subsequently, in the fourth section of this paper, we detail a German case study to empirically support our argument by looking at the city of Heidelberg, which is considered to be a "knowledge pearl" in Germany. This city certainly shows a high overall growth rate and economic stability due to knowledge-led urban development - as the knowledge discourse suggests. At the same time, however, Heidelberg struggles with consistent patterns of inequality that increasingly question this rosy picture. Our case study is drawn from long-term observations in this city, an active involvement in urban planning issues—-such as the spatial expansion of the University — as well as the relaunching of an urban growth model. In addition, 
we draw on our experience with the operation of the real-world lab Urban Office of Heidelberg that has partaken in sustainable urban development for several years in close cooperation with the International Building Exhibition (Internationale Bauausstellung, IBA Heidelberg), the city of Heidelberg, and urban society activists (see Gerhard \& Marquardt, 2015, 2017). We contend that such an empirical investigation is a necessary element in any conceptualizations of knowledge-related urban development. In the final section, we draw out some implications of our analysis for the wider concerns that are motivating this edited volume.

\section{Urban Development in Knowledge Society and the Role of Institutions of Higher Education}

In post-industrial times, it is common to see knowledge as a fundamental resource for the development of cities. The transition from an industrial to a knowledge society has shaped the character of urbanity and has forced cities into global competition (e.g., Knight, 1995). They compete for creative talent, successful enterprises, financial support, job opportunities, and a better quality of life. In this contest, knowledge-based institutions such as schools, colleges, universities and other institutions of higher education, science and research centers, libraries, hospitals, and research-focused and creative industries all gain increasingly strategic importance for successful urban development (Florida, 2002; Scott, 2006). The support of these branches has become a focal point in local and regional policies (e.g., Anheier \& Isar, 2012) and emerged into an important task in urban planning administrations (e.g., Evans, 2009; Fröhlich, 2021).

The provision and management of space for knowledge production, distribution, and integration has thus taken on new significance in recent years (Kujath, 2012; Yigitcanlar, 2009). It involves the supply of additional areas for offices and labs, for knowledge intensive enterprises, for creative start-ups, for institutions of higher education, and for attractive housing for the knowledge workers. A further aspect is the provision of opportunities for the informal exchange of knowledge in order to foster the development of creative milieus (Florida, 2005). Creative milieus are contexts for working and learning, living and perception, as well as cooperation and competition (Matthiesen \& Mahnken, 2009; Merkel, 2012). They nurture the innovation-driving, creative, and cultural industries - all of these branches essentially being dependent on knowledge exchange (Kunzmann, 2004; Landry, 2008). Short distances between different organizations, available meeting points, and urban open spaces nourish a creative atmosphere, which then attracts further stakeholders. "Place matters, because a stimulating environment and a talented individual must come together and interact before a creative process can occur" (Meusburger, 2009, p. 98).

This also holds true in view of digitization. Face-to-face contacts can be reduced to a certain extent and the use of home offices is on the rise, but what is lost must be 
replaced by new forms of trust relations that bear spatial implications (Growe, 2019). The development of new quarters as knowledge hubs is one option. Brownfield areas, for example, can be used to sustain knowledge parks, technology facilities, creativity centers, or institutions of higher education in one location, thus providing possibilities for networking and linkage. These networks are strongly linked to residential opportunities and urban neighborhoods. Another option is campus development by turning university sites into public arenas for discourses and knowledge production by a broad range of stakeholders with a great deal of expertise on different topics. Thus, a clear connection of place and knowledge is important: Cities are increasingly competing to attract creative minds and young people. To do that, a charming surrounding area, diverse cultural and sports activities, and public spaces are substantial aspects. Only when the provided amenities meet these needs can a city succeed in attracting skilled and educated people (Storper \& Scott, 2009).

Many studies highlight universities and other higher educational institutions as key actors in the process of knowledge appropriation (e.g., Addie, 2018; Chatterton \& Goddard, 2003; Goddard \& Vallance, 2011). Leading global cities, for example, exhibit a comparably high rate in higher education institutions, and their economic success is attributed to the presence of high-ranking universities (Addie, 2018; Jöns \& Hoyler, 2013). Silicon Valley seems impossible without Stanford University; the boom of Munich is bound to its excellent universities and other knowledge institutions; and, last but not least, China strategically locates key universities in important cities (Liu, 2019). This, however, also holds true and might be even more relevant for smaller and medium-sized cities where institutions of higher education became key players in the process of urban change (e.g., for Queensland University of Technology, Massachusetts Institute of Technology, Harvard, Twente, and Newcastle universities see Benneworth, Charles, \& Madanipour, 2010; for Oxford, Leuven, and Pisa see Lazzeroni \& Piccaluga, 2015; for Cachoeira see Baumgartner \& Rothfuß, 2017).

Universities and colleges affect their host cities at multiple levels (Delanty, 2001; Maasen, Andreadakis, Gulbrandsen, \& Stensaker, 2019). They decisively contribute to education and qualification within a city. Their members not only educate students and $\mathrm{PhD}$ candidates but also offer continuing training, public science, and knowledge transfer into civil society, administration, and industry (Marquardt, 2019). Through their role as a main employer in a region, they strongly foster economic development (Glückler, Panitz, \& Janzen, 2019). At the same time, institutions of higher education also directly affect urban space. Nurturing in numbers-numerous universities were founded during the last century around the globe — and size, the quantity of students in cities has risen enormously as has the number of researchers (Hoelscher, 2012, p. 1714; Hoelscher \& Harris-Hümmert, 2019). This again puts universities in strong competition for land with other urban stakeholders.

Thus, institutions of higher education become very influential for a city's sociostructural development. As Addie and colleagues have put it in a nutshell: "The sociospatial impacts of higher education's massification and commercialization, together with the deep restructuring associated with the new knowledge economy, are of paramount importance for our understanding of contemporary urban and 
economic development" (Addie et al., 2015, p. 33). At the same time, however, the impact of knowledge-intensive institutions and industries on the urban context differs markedly, as shown in various analyses. Considering the involvement of the knowledge sector in the economic development of cities, van Winden et al. (2007) generate six types of knowledge-based cities in northwest Europe, reaching from stars (larger cities scoring high in all seven dimensions) to knowledge pearls (smaller cities within or near an agglomeration scoring high in all seven dimensions). The latter type is true for our case study of Heidelberg, as we will show later. In another quantitative study on North American city regions, Gabe et al. (2012) extract eleven different knowledge profiles according to their share of employment in knowledge-related industries. The profiles range from making regions (high score for knowledge on manufacturing) up to teaching regions (college towns with high knowledge on education and training). Knowledge-induced growth, therefore, comes in quite different forms and with a diverse range of outcomes, as visible if one focuses on knowledge-based urban development within the cities themselves. The clear prioritization of aspects of knowledge, such as creativity and innovation, favors certain areas (mostly in close proximity to the knowledge sites), whereas other areas are left out. Booming regions especially are marked by a strong disparity between knowledge quarters and peripheral neighborhoods, as discussed in the next section.

\section{The Dark Side of Prosperity: Urban Inequalities in the Knowledge City}

The authors of a growing body of literature question the generally positive evaluation of knowledge-based urban development. Bontje and Musterd (2009), for example, criticize that it is mainly a fashion fueled by "scientist-consultants," whereas a more pessimistic view is based on local experts from seven European city-regions. Similarly, Rausch and Negrey (2006) are skeptical about a positive relationship due to their empirical correlation analysis of Florida's creativity ranking and economic data of the cities at which they looked. Even when one acknowledges the innovative capacity of knowledge institutions for a region, there is a "dark side of prosperity" (Walker, 2018). Knowledge-led growth produces uneven developments because not all parts of the urban society profit from it. There is, first of all, the strong structural fact that not all former blue-collar jobs can be easily transformed into white-collar service jobs. As researchers like Friedmann (1986) and Sassen (1991/2001) already observed and forecasted for the development of highly connected global cities, labor markets in cities are strongly polarizing related to the growth of the knowledge and information society. Even more, the advance of the service industries (especially the so-called FIRE Sector composed of finance, insurance, and real estate; quintessential for the global city) produces a growing demand of low-skilled services necessary to keep the urban infrastructure of the knowledge society running. From cleaning to security, from call centers to hotel receptions, demand for 
low-skilled work is increasing-whereas wages are decreasing. As McDowell and Dyson (2011) have shown, this especially affects female workers, as well as migrants, who constitute a large part of the often unsecured, low-paid service industries (precarious jobs). At the same time, an erosion of the middle class can be detected because more people can reach upper levels of social mobility (due to broader education and knowledge), whereas others, whose skills are not needed anymore in post-industrial societies, are filtered down into the lower levels of social class.

Second, there is a strong sociospatial component to knowledge-induced growth. Described with different opalescent terms, such as urban redevelopment, downtown revitalization, or reurbanization, inner cities, which used to be the home of ethnic groups and heterogeneous milieus, are now being gentrified into upscaled neighborhoods catering mainly to the new urban knowledge workers. Formerly neglected neighborhoods are becoming cool places that still reveal "gritty" authenticity from their past (Zukin, 2011, pp. 35-37) while displacing people from groups less inclined to education or with lower-income from these districts. Wilson (2018) talks about "urban growth machines" that transform these neighborhoods into touristy places that appeal especially to the transnational elite.

Third, even when an overall positive quantitative impact of knowledge institutions on regional development is ascertained, the local innovative outputs differ from case to case (see, e.g., Warnecke, 2018). Some studies state that researchers looking for excellence in research cooperation are often oblivious of their regional environment and the local labor market (Kroll, Dornbusch, \& Schnabl, 2016). Thus, only stronger regions might profit from an excellent university due to an already existing innovative and creative milieu. This is the case, for example, for university sites such as Stanford, Harvard, Leuven, Groningen, or Munich. In general, however, a local involvement and prosperous cooperation between town and gown cannot be taken for granted and the role model of Silicon Valley, borne out of the seedbed of a university, cannot be transferred to every case (Hall, 1997; Knight, 1995).

From a quantitative point of view, the measurement of a university's economic impact on the surrounding region is highly dependent on the definition of the area, the use of indicators, and the role of multipliers (Siegfried et al., 2007). Furthermore, the assessment of the university's regional effect is embedded in a neoliberal framework that accounts for purely economic output, but neglects social, political, and local contexts or consequences (Bose, 2015). Audretsch (2014) argues that the university's role has shifted from an "entrepreneurial university to the university for the entrepreneurial society" (p. 313). Whereas the former was a call on universities to become more flexible, interdisciplinary, and application-oriented, as an "entrepreneurial" response to the increased demands on institutions of higher education from outside academia (Clark, 2001), the latter is a call to enhance entrepreneurial and human capital and facilitating behavior in an entrepreneurial society.

Last but not least, cities with strong universities and creative regional environments experience the highest pressure on the global real estate market. Silicon Valley and the Greater San Francisco Bay Area may sit atop galloping real estate 
prices, but the sheer numbers and, even more, the sheer discrepancies of prices between and within cities in general are striking. North American cities in thinking or innovating regions (strong in IT, commerce, arts, and humanities but low in manufacturing; see Gabe et al., 2012) experience the highest growth rates of house or rental prices in comparison to all other cities. For Germany, Egner and Grabietz (2018) found two main factors that significantly impact high rents: mean income and the number of students. Higher prices, as we will show for our case study on Heidelberg, create substantial inequalities within the urban context and thus threaten the quality of life in many cities. When space is a scarce resource in competitive cities, intra-urban conflicts between different land uses arise. In addition, newly built quarters are especially tailored to the needs of academic singles, young couples, and families, providing urban flair through stylish restaurants, internationalized shops, and green spaces. This often comes with an upturn in rental and real estate prices-causing new social inequalities or even changing the character of whole quarters, as studies on "studentification" in Great Britain have shown (Smith, 2004).

Touristification, platform urbanism, and sharing economies are just a few more catchwords that, even though they sail under the flags of sustainability and authenticity, exert enormous pressure on local real estate markets. Cities as the growth engines of knowledge economies thus attract creative people and well-heeled visitors by promoting certain cool, fancy, or creative areas to the disadvantage of others.

For these reasons, the knowledge discourse needs to be closely related to the issue of urban inequalities and the factors that help (re-)produce them, such as the educational sector. While analyzing inequalities has a long tradition in urban studies (for an analytical overview, see Heynen, Aiello, Keegan, \& Luke, 2018), the formation of the knowledge society has only received rudimentary attention in that context. There are, for example, a growing number of studies on social and spatial inequalities of educational opportunities and school access, especially for the U.S.American context (see, e.g., a special issue in Urban Studies, Vol. 56, Issue 15, 2019). In addition, the authors of several studies have shown the connection between place of residence and the educational disadvantage of pupils with a migrant background (e.g., for Germany, Baur, 2013). These studies, however, are mostly embedded into segregation discourses that are related to race, class, and socioeconomic measures; their authors mostly provide quantitative evidence for a complex sociospatial context of school segregation (e.g., Boterman, Musterd, Pacchi, \& Ranci, 2019; Oberti \& Savina, 2019; Owens \& Candipan, 2019) and hardly ever frame their work within the broader picture of knowledge society. Thus, they lack a comprehensive, interdisciplinary approach with which to equally analyze educational systems, knowledge discourses, and uneven urban developments, as suggested in the next section. 


\section{Linking Urban Inequalities to Education}

Education plays an increasingly important role in the knowledge society, as educational achievements result in benefits in many realms of life, including better and safer jobs, increased health and well-being in general, and more social and political engagement. However, educational achievements are still unevenly distributed and are, inter alia, dependent on socioenvironmental settings. These settings, and especially the spatial distribution of educational institutions and their use, are influenced by current trends towards knowledge-based urban development. Before looking at the socioenvironmental settings in more detail, we want to address the relationship between education and inequality as a reciprocal one more generally.

First, scholars well accept that education is actively producing social inequality: Formalized educational degrees are influencing access to labor markets, especially to higher positions (e.g., Hillmert, 2011), and many researchers have shown the positive impact of education on (economic) well-being on the individual level (e.g., Harmon, Oosterbeek, \& Walker, 2003; Woessmann, 2016). From a meritocratic point of view, this relationship between educational success and individual wellbeing is seen as legitimate, as long as there are equal chances with regard to educational achievements. As the term knowledge society suggests, proponents regard education as the main mechanism transferring ability and effort via certified degrees into (access to) higher social positions, resulting in upward social mobility and thus differentiation. Education, therefore, is not only producing inequality, but, even more, it is also legitimizing it (see also Hadjar \& Becker, 2016).

Second, contrary to this legitimization, authors of empirical findings prove that equal access to educational opportunities is a "myth" (Goldthorpe, 2003). The reason is that the relationship between education and social inequality also works the other way around: Social inequality or background is heavily influencing educational achievement. The interplay of social origin $(\mathrm{O})$, education $(\mathrm{E})$, and social destination (D) can be conceptualized in the O-E-D-triangle (e.g., Hadjar \& Becker, 2016) (see Fig. 2.1).

Some empirical researchers have indeed shown a decreasing influence of social origin on education as well as on social destination during the twentieth century,

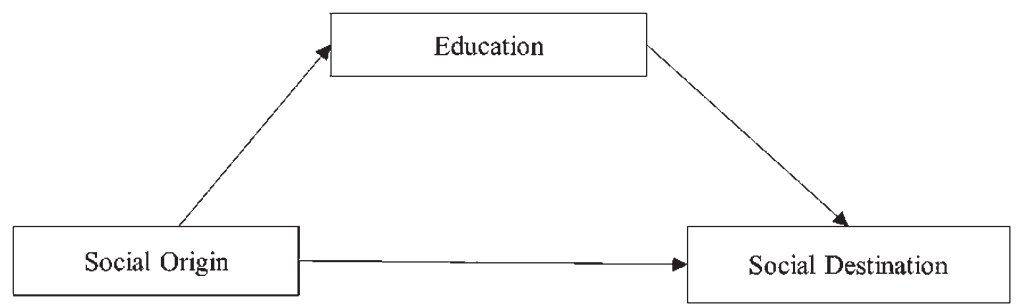

Fig. 2.1 The relationship between social origin, education, and social destination. Source: Design by authors 
especially in the 1960s and 1970s (Breen, Luijkx, Müller, \& Pollak, 2009), but by no means a disappearance (Goldthorpe, 2003; Pollak \& Müller, 2018). With regard to the overall picture in the last decades and today, Hadjar and Becker (2016, p. 252) even conclude: "The link between educational attainment and class of destination (E-D) decreased, while the (direct) link between class of origin and destination class (O-D) slightly increased." Barone and Schizzerotto (2011), in their summary of a comparative study on five European countries, reach a similar result. ${ }^{1}$ Bukodi and Goldthorpe (2013) differentiate three different dimensions of social origin: namely, class background, level of education, and social status. In their study comparing three British birth cohorts, they find (a) persistent levels of inequalities, which they link especially to "secondary" effects (Boudon, 1974), which are effects stemming not from differential performance in school, but from educational decisions; and (b) that "it is parental education that is of greatest, and increasing, relative importance" (Bukodi \& Goldthorpe, 2013, p. 1034).

A first conclusion therefore is that contrary to modern society's promise of reducing the inheritance of social status and an increasing reliance on education as a just means for social mobility, the knowledge society instead increases the influence of social origin, and especially parental education, on educational achievements. Why is this the case?

As already mentioned above, (educational) inequalities have a spatial or socioenvironmental dimension. An important aspect is the local availability of educational infrastructure and its quality. Burger (2019, p. 182), reporting on Europe, finds evidence "of the potentially damaging effect of a sociospatial separation of students, indicating that socioeconomic segregation ... may contribute to some extent to the perpetuation of educational and, by extension, social disadvantage from one generation to the next." Scholars are engaging in an extensive discussion on school choice and (changing) places of residence. While this topic is not new (see, e.g., already the classic studies by Coleman and others), there seems to be a growing significance in the context of the knowledge society. Lipman $(2002,2011)$, for example, relates inequality to the new political economy of education and argues that neoliberal school reforms in Chicago have exacerbated the already existing inequalities in the urban landscape. Candipan (2019; Owens \& Candipan, 2019) showed that even with the introduction of free school choice or the establishment of charter schools in the U.S., inequalities between the schools - which were supposed to diminisheven increased, because higher-income parents tend to bypass schools with higher proportions of minority or low-income students and enroll their children outside their (gentrifying) neighborhood. This is because well-off parents are able and eager to use available information on school quality to send their children to good schools, and even possess the financial resources to move to another place if necessary. ${ }^{2}$ For Germany, researchers have shown that "the absence of a desired school in the

\footnotetext{
${ }^{1}$ However, the setup of national educational systems seems to play an important role in the precise amount of these effects (see also Hadjar \& Gross, 2016).

${ }^{2}$ As some anecdotal evidence: There is, for example, an app that helps one find the right accommodation in Oxford if one wants to live in the catchment area of a specific school.
} 
immediate vicinity drastically increases the relocation rate. In addition, families with university degrees and without a migration background move more frequently to neighborhoods with few perceived signs of deprivation" (Oeltjen \& Windzio, 2019, pp. 651-652).

From a relational perspective, educational achievement is not only influenced by the described family background and decisions, but more broadly by effects of collective socialization, such as the influence of local social networks (Zangger, 2018). There is sufficient evidence that disadvantaged districts can therefore become disadvantaging districts. Researchers have recently shown, however, that the opposite effect seems to be even more pronounced: Advantaged surroundings seem to foster advantaged children even more strongly (Helbig \& Jähnen, 2018; Zangger, 2018, with an extended discussion). And although, in general, ethnic segregation is less pronounced in Germany than, for example, in the U.S., authors of a recent study have shown that social segregation is growing and especially affects families with children (Helbig \& Jähnen, 2018). Interestingly though, the availability of private schools seems to possibly reduce spatial social segregation, as such schools allow better-off parents to stay in the quarter and send their children to these institutions. This, however, is producing another kind of segregation, contributing to what is sometimes discussed under the "qualitative dimension" in the concept of "effectively maintained inequality in education" (e.g., Lucas \& Byrne, 2017; for Germany, Weiss \& Schindler, 2017).

A second conclusion, therefore, is that the influence of social origin on educational achievements is created by the interplay of individual decisions and urban spatial structures. Our hypothesis is that knowledge-based urban development impacts these individual decisions as well as the polarization between different city quarters, thereby contributing to (new) urban and social inequalities.

In general, Germany seems to be a good case study for the analysis of the relationship between education, inequality, and the city for several reasons. First, authors of extensive reviews have shown "that a high degree of stratification . . increases inequality in ... educational attainment" (Combet, 2019, pp. 301-302). Germany has a highly stratified and diversified school system, combined with a strong focus on certificates in the labor market. Children, after their first four years in joint local schools (called Grundschulen with catchment areas), are selected into two tracks of secondary education: Haupt-/Realschulen (another 5 or 6 years of schooling, mainly preparing for vocational education and training) and Gymnasium (another 8 or 9 years, on the main road into higher education). Although access to the different types of schools is open for all children and does not depend on parental income or position, there are sturdy differences between social groups. The relationship between social origin and social destination is strong and highly mediated via education (Hillmert, 2011; OECD, 2016, p. 214; Weiss \& Schindler, 2017). Second, with increasing numbers of private schools, a rapidly expanding higher education system, and other developments, the educational context has changed dramatically in recent years, combined with only sparse research in this field up to now (Helbig \& Jähnen, 2018, p. 69). 
Heidelberg is an interesting case in this respect, as it is a city with one of the highest participation rates in the Gymnasium (the highest track at the secondary educational level). It is also the location of one of Germany's most prestigious universities, which is at the same time the largest employer within the city, and it is a town with some of the highest housing prices. The sociospatial outcomes, therefore, might be especially visible.

\section{The Example: Heidelberg}

In the previous sections, we have argued that education, knowledge society, and urban development are closely related and together produce and reproduce different layers of inequality. With our case study of Heidelberg, a midsized college town and internationally esteemed "knowledge pearl" in Germany (van Winden et al., 2007; see also Meusburger, 2016) that is potentially characterized as a "thinking region" according to Gabe et al. (2012), we contend that Heidelberg's knowledge-based urban development is inherently related to (educational) inequality and segmentation. The urban landscape is highly structured by the university and other knowledge institutions and their employees, urban space is negotiated as a competitive resource that produces conflicts and displacements, and housing in central areas becomes for many an unaffordable asset that-although homelessness is not the biggest issue in the German welfare context-increasingly affects quality of life issues. On the neighborhood scale, residents have strongly entrenched social statuses, mostly related to the educational background that is already visible at the elementary school level. Thus, the strong interplay of knowledge society, education, and urban development bears sociospatial outcomes that can be illustrated with the case study of Heidelberg.

Heidelberg, situated in the flourishing Rhine-Neckar metropolitan region, is increasingly distinguishing itself as a knowledge city. The university and other institutions of higher education, several prestigious national and European research institutions, and a research-based corporate landscape have contributed to Heidelberg's dynamic development during the last decades. Large numbers of job opportunities are connected to knowledge institutions and the tertiary sector is thriving. This progress attracts new inhabitants, as seen by the fact that the urban population increased from almost 140,000 in 2000 to more than 160,000 today. The number of students and academics living in the city is especially increasing. The share of students in the city population has grown from $21.5 \%$ (2010) to $24.1 \%$ in 2016 , or from 30,893 to 37,624 students in absolute terms (Eurostat, 2020). In 2019, Heidelberg was judged the German city with the highest rate of academics among its employment population-44\% (Burstedde \& Werner, 2019). However, this also causes a high rate of social inequality. Ninety people with incomes in the millions are opposed to $28 \%$ of the population earning less than $€ 10,000$ a year (Stadt Heidelberg, 2018a). However, this high proportion of low earners is probably also due to the high number of students (ibid.). Do these disparities also become 
spatially apparent in the city of Heidelberg when we include education as a further aspect?

One of the central arguments made above applies to segregation along educational achievements. The spatial distribution of the employment population's educational degrees is characterized by strong discrepancies between the different neighborhoods in Heidelberg (see Table 2.1; see Fig. 2.2 for their location in Heidelberg). In 2019, three groups are distinguishable: In a first group of neighborhoods (Altstadt, Bergheim, Weststadt, Südstadt, Handschuhsheim, Neuenheim, and Bahnstadt), more than $70 \%$ of the working population hold at least an Abitur or Fachabitur, the educational level needed for university entrance qualification. A second group of neighborhoods, consisting of Schlierbach, Rohrbach, Kirchheim, Wieblingen, und Ziegelhausen, has a share of graduates with Abitur between 50 and $70 \%$. On the other end of the educational spectrum lie the more peripheral locations with much lower rates: In Pfaffengrund, Boxberg, and Emmertsgrund less than $40 \%$ have this high school diploma (third group).

As laid out in Table 2.1, these differences have (slightly) increased over time: The overall share of the working population with at least an Abitur in Heidelberg rose by 8.3 percentage points by 2019 . Above-average increases can be found in Bergheim (new social science campus on a redeveloped brownfield site) and Handschuhsheim (Group 1), as well as in Rohrbach and Wieblingen (which has the $S R H$, a growing private University of Applied Sciences, as well as a popular private Gymnasium, Group 2). The already low areas of Pfaffengrund, Boxberg, and Emmertsgrund (Group 3), as well as Südstadt, however, exhibit below-average

Table 2.1 Share of employed people with (Fach-)Abitur as highest educational degree by place of residence (in \%, 2014 and 2019)

\begin{tabular}{lccc}
\hline Neighborhood & 2014 & 2019 & Change \\
\hline Altstadt & 68.8 & 76.6 & 7.8 \\
Bahnstadt & 77.8 & 86.0 & 8.2 \\
Bergheim & 62.8 & 71.5 & 8.7 \\
Handschuhsheim & 62.7 & 72.0 & 9.3 \\
Neuenheim & 77.0 & 81.4 & 4.4 \\
Südstadt & 65.2 & 71.1 & 5.9 \\
Weststadt & 70.9 & 78.0 & 7.0 \\
Kirchheim & 43.4 & 51.5 & 8.1 \\
Rohrbach & 51.1 & 59.7 & 8.6 \\
Schlierbach & 59.6 & 67.6 & 8.0 \\
Wieblingen & 45.4 & 55.6 & 11.2 \\
Ziegelhausen & 50.7 & 58.5 & 7.8 \\
Boxberg & 25.7 & 31.8 & 6.1 \\
Emmertsgrund & 23.2 & 29.0 & 5.8 \\
Pfaffengrund & 29.9 & 35.9 & 6.0 \\
Total Heidelberg & 54.7 & 63.0 & 8.3 \\
\hline
\end{tabular}

Note. Source: Design by authors. Data from Stadt Heidelberg, Statistics of the Federal Employment Agency 


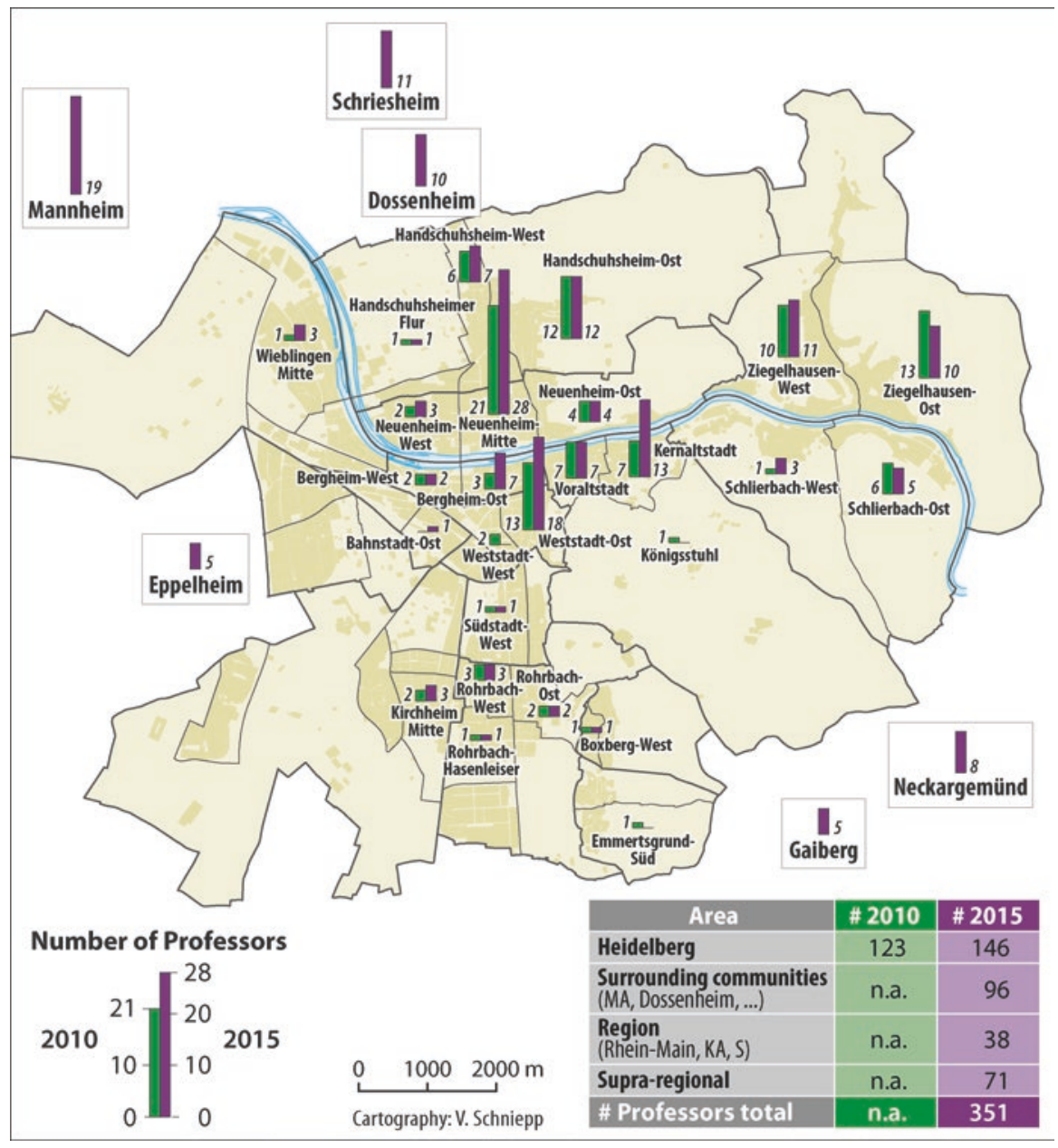

Fig. 2.2 Places of residence of university professors at Heidelberg University (absolute numbers, 2010 and 2015). Source: Design by authors. Data from Heidelberg University

growth rates. Interestingly, Neuenheim has the lowest growth rate, but was in 2014 and still is in 2019 the quarter with the second highest share of citizens with Abitur. A potential explanation might be that Neuenheim is a very settled urban area with the highest overall rents in Heidelberg.

Interpreting these numbers, a clear spatial pattern becomes obvious: The (most prestigious) neighborhoods adjacent to the three university locations (Neuenheim and Handschuhsheim next to the modern science campus, Bergheim and Weststadt next to the new social science campus, and the old city center Altstadt with the humanities dispersed throughout it) exhibit the largest shares of higher-educated citizens and, in most cases (with the exception of Neuenheim), show above-average growth rates. This results in increased polarization within the city. 
Examining the places of residence of professors of Heidelberg University reveals a pretty similar picture (see Fig. 2.2). Most live in the affluent neighborhoods that are close to the University, very few live in the Southern part of the city, and literally none reside in Emmertsgrund, the poorest high-rise housing area. This trend increased between 2010 and 2015, with the highest gains for the first group of city quarters (Weststadt +3 , Bergheim +4 , Altstadt +6 , and especially Neuenheim +8 ) and losses only in Ziegelhausen (-2) and Emmertsgrund (-1). In addition, a further trend is also becoming apparent: a trend towards suburbanization driven by searches for single-family housing in attractive locations. Out of 351 professors at Heidelberg University, 96 live in suburbs, and 109 are even commuters from other cities. Again, it is striking to note the spatial concordance between neighborhoods with high numbers of university professors living in them and neighborhoods whose inhabitants have the highest educational degrees.

As argued above, knowledge-based urban development and related segregation, evidenced here with regard to educational disparities, should also play out in economic terms. And, in fact, the comparison of rent indexes across the different city quarters displays similar patterns once more. Calculating the lowest rent in town as the standard (found in Boxberg and Emmertsgrund in 2019), we find strong deviations from that norm (see Fig. 2.3). Neuenheim and the adjacent areas of Handschuhsheim, Bergheim, and Altstadt (Group 1) have average rent prices more than 30 or $40 \%$ above the calculative norm. We also detected gentrification processes in Bergheim, with the newest campus site, which used to be a mixed-use neighborhood with low rents that are now gradually disappearing from the urban landscape, undergoing the largest increase in rents between 2011 and 2019 for the whole of Heidelberg. Boxberg (-5\%), Kirchheim (-4\%), and Pfaffengrund (-6\%), on the other side, move closer to the least expensive quarters (Group 3).

The residents' varying involvement in the labor market in the different neighborhoods accentuates this pattern: The lowest unemployment rates can be found in the above-mentioned prestigious neighborhoods, whereas they are highest in Emmertsgrund, Boxberg, and Pfaffengrund. Overall, a spatial divide exists between a high socioeconomic status in the north and the less-educated, much lower income south/west.

To what extent do these disparate socioenvironmental contexts impact Heidelberg's educational inequalities? In the paragraphs above, we reported on studies whose authors have shown that deprived neighborhoods can become depriving neighborhoods. From the described patterns, we argue that this is increasingly also the case in Heidelberg, with the most highly educated people increasingly concentrating in certain quarters, often near central knowledge institutions such as universities. Although we are not able to track relocation processes of individuals within Heidelberg, there is aggregated data that people in the age group 30-39 $(47 \%)$ and those with small children (58\%) were especially prone to moving house within Heidelberg during the last 5 years (Stadt Heidelberg, 2018b). ${ }^{3}$ As Oeltjen and

\footnotetext{
${ }^{3}$ These are often former students who find a job after graduation and start a family.
} 


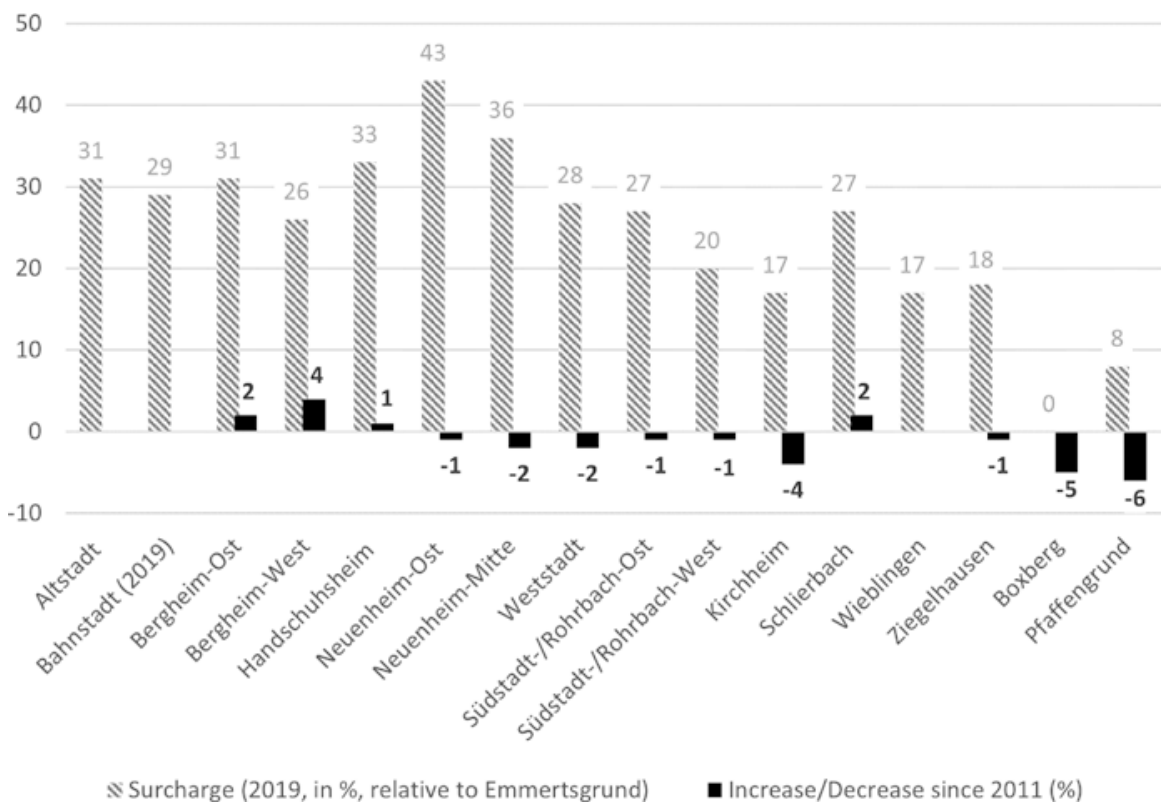

Fig. 2.3 Rent index zones in Heidelberg and their changes, 2011 and 2019. Source: Design by authors. Data from Stadt Heidelberg $(2011,2019)$

Windzio (2019, see above) have shown, well-educated parents especially choose privileged neighborhoods with good schools when moving, whereas less educated parents with lower incomes have to move to deprived neighborhoods due to the huge differences in rents.

Looking at the distribution of Gymnasiums, we find three in Neuenheim (one public, two private ones), two in Altstadt (both public), three in Rohrbach (two public, one private), ${ }^{4}$ and one in Wieblingen (private). A special characteristic in Heidelberg is the huge share of pupils in private Gymnasiums (around 50\%). Even more interesting, however, are the school transition rates for pupils from elementary school (Grundschule) to Gymnasium, where the strongly inherited character of educational degrees becomes obvious (see Table 2.2). As the (public) elementary schools in Germany have catchment areas, these figures are directly related to the respective neighborhoods.

The concordance between the different neighborhood groups is striking. Elementary/primary schools (grade 1-4) in the first group of neighborhoods (high proportions of college degrees) possess much higher shares of kids going to the high schools in town (Gymnasium), with figures (well) above $80 \%$ in all schools of Altstadt, Neuenheim, and Handschuhsheim, and at least in one school in Weststadt. For example, Mönchhofschule in Neuenheim and the Friedrich-Ebert-Schule in the

\footnotetext{
${ }^{4}$ One of the public institutions is a Gesamtschule, combining a Gymnasium with other school tracks; the private one was traditionally connected to the American soldiers located in Heidelberg.
} 
Altstadt sent all verifiable pupils to the Gymnasium in 2018/19, and the Heiligenbergschule all but seven pupils. This is in clear contrast to other neighborhoods, especially in the southern, more peripheral parts of the city (e.g., Waldparkschule or Emmertsgrund, Group 3), where only few pupils reached that level. The professional future and thus expected income of the latter will be strongly influenced by this fact (see previous section).

Interpreting these numbers over time, an entrenchment of these patterns becomes visible: There are (further) increases of around, or even above, ten percentage points for school transfer to the Gymnasium in the Altstadt, Weststadt, and Wieblingen, but also in Kirchheim (still low overall level) and (one school in) Rohrbach. Decreasing shares are reported for Boxberg (see the respective footnote, though), Emmertsgrund, and Bergheim; all three also have the lowest absolute figures of pupils overall. The overall pattern of strong disparities is maintained and, in many cases, even solidified. The only exceptions to this striking picture are Schlierbach and one school in Rohrbach.

Further socioeconomic measures could be discussed here at length, but the main message is clear: The case of Heidelberg is marked by a strong relationality between education, knowledge society, and uneven urban development. City areas near university locations have the highest rates of well-educated inhabitants, the highest rents, and the highest level of pupils reaching the highest level of school education. City quarters that are further away from university amenities are less well off. If we correlate these aspects statistically, we find strong to very strong relationships between the different variables. ${ }^{5}$ For example, the coefficient of determination $\left(\mathrm{R}^{2}\right)$ for employed people with Abitur is 0.5 for professors' residency, 0.9 for rent surcharges, and 0.7 for school transitions to Gymnasium. The figure for rent surcharges and school transitions is 0.69 . This latter number means, for example, that nearly $70 \%$ of the variance between neighborhoods with regard to school transitions is related to rent differences. Where longitudinal data is available, this relationship seems to strengthen over time. The university, therefore, is an important player in present urban society. Due to the university's very strong expansion during the last decades, with a new campus in Bergheim and an enormously growing campus in Neuenheim, the city is changing quickly. The city administration's emphasis on fostering the development of the university and other knowledge-focused stakeholders and on supporting the transformation into a "knowledge city Heidelberg" fails to include some of the city neighborhoods and, to a large extent, the people living there. By concentrating on promoting science, these districts continue to be disadvantaged places.

\footnotetext{
${ }^{5}$ We leave out the Bahnstadt as a very new (the very first inhabitants moved there in 2012) and specific neighborhood. See our discussion in the conclusion. Correlations, however, decrease only slightly when taking it into account $(0.31,0.9,0.62$, and 0.67 respectively).
} 
Table 2.2 School transfers from elementary school to Gymnasium in Heidelberg (in \%, 2013/14 and 2018/19)

\begin{tabular}{|llrrr}
\hline Neighborhood & Elementary School & $2013 / 14$ & $2018 / 19$ & Change \\
\hline & & & \\
& & & \\
& & & \\
& & & \\
& & & \\
& & & \\
& & & \\
& & & \\
Kirchheim & Geschwister-Scholl-Schule & 35.1 & 34.9 & -0.2 \\
& Kurpfalzschule & 44.4 & 56.7 & 12.3 \\
Rohrbach & Eichendorffschule & 62.7 & 78.9 & 16.2 \\
Schlierbach & IGH Primarstufe ${ }^{\mathrm{a}}$ & 26.0 & 30.3 & 4.3 \\
Wieblingen & Schlierbach Grundschule & 84.4 & 75.8 & -8.6 \\
Ziegelhausen & Fröbelschule & 61.7 & 74.6 & 12.9 \\
& Grundschule Ziegelhausen & 72.2 & 69.7 & -2.5 \\
& & & & \\
& & & & \\
& & & 63.9 & 1.2 \\
\hline
\end{tabular}

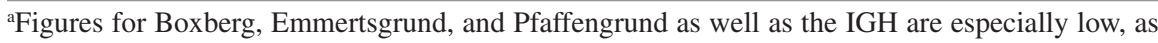
they send around a quarter of their pupils to the so-called Gemeinschaftsschule, which opens a path into the Gymnasium at a later stage for some pupils

Note. Source: Design by authors. Data from Stadt Heidelberg, Amt für Schule und Bildung, different years

\section{Conclusions/Extrapolations}

Educational institutions, and especially universities, play an increasingly important role in the knowledge society. As we have detailed in this paper, educational achievement, but also educational institutions themselves, are heavily intertwined with issues of social and spatial inequality. Cities are those places where these reciprocal processes are culminating in the most visible way. The authors of a wealth of literature have already dealt with urban inequalities, including in recent urban studies. This literature ranges through discourses on the global, the neoliberal, the postcolonial, and the mega city. In addition, educational scientists increasingly focus on unequal access to schools and educational systems. What is lacking, however, is a broader view to combine these different strands of research in order to develop a more complex picture of urban inequalities in the knowledge society. In this paper, we have argued that a reciprocal relationship exists between social origin and social destination, one that is especially pronounced in the currently acclaimed knowledge city. Although knowledge is a broad term and seems to be increasingly available for 
everybody, its utilizers differentiate between groups of people and stratify individual well-being. Departing from the "meritocratic myth" that knowledge and education offset the direct causation of social origin and social destination, we claim that education in knowledge societies contributes to a stratified and polarized population-especially in cities.

In our case study of Heidelberg, we tried to pin down some aspects of this interplay. Even though Heidelberg is a city with a considerably wealthy population and an overall low rate of people dependent on welfare state transfer payments, we find a largely uneven distribution of knowledge opportunities in the city. Especially in the context of neoliberally interpreted knowledge policies, the already well-off are those profiting the most from the growing educational sector. Looking at educational success, for example, we have found a connection between neighborhood and school career. (Growing) segregation within the city leads to differing educational opportunities for people, especially children, in the different neighborhoods. The availability of good schools influences middle-class parents' decision on places of residence, and rising rents limit access to better-equipped districts to the already well-off. As a result, neighborhoods adjacent to university facilities especially benefit.

These identified effects will probably be further strengthened by the current urban policy with its emphasis on knowledge. Heidelberg started developing a new city neighborhood, Bahnstadt, in 2009, with the first residents moving there in 2012. However, the focus on sustainable construction entails high rents for housing, so that a fairly homogeneous population emerged-many double income couples, families, and the well-educated (Herrmann, 2020). Well-equipped educational facilities, often with additional support from foundations, are established in this already privileged neighborhood. Other social groups and city areas are left behind. Great attention is also paid to another strand of urban development in Heidelberg: the future-oriented planning process of the campus Im Neuenheimer Feld. This campus hosts university faculties and further research institutions, hospitals, a technology park, and other knowledge-based stakeholders. Again, a large part of the city's resources is tied up in this planning process with a focus on the university and other knowledge actors. In addition, in 2012, the city started a 10-year developing process, called Internationale Bauausstellung (International Building Exhibition, IBA) with the topic of "Wissen-schafft-Stadt [Knowledge-based urbanism]." The aim is to develop "urbanistic projects for the knowledge society of the future" (Internationale Bauaustellung Heidelberg, n.d.). One important project is the transformation of the Patrick Henry Village, a military brownfield area in the Southwest of Heidelberg. Under the slogan "Knowledge City of Tomorrow," the IBA is developing a vision for a modern city district that will be both a place to live and work and a model for sustainable and innovative urban development. All in all, the urban development in Heidelberg shows the important role of the university and other knowledge institutions within the process of urban development. For the city, the support of the university and other knowledge-intensive stakeholders is important to succeed in the inter-urban competition-a declared goal of the 
municipality — and shall pave the way to a promising future. This future, however, is not open to everybody.

Although the empirical details on Heidelberg are important, we want to conclude this paper by addressing the increasing role universities or other higher educational systems are playing in the global network of knowledge exchange and societal development. It is the task of university members and researchers to contribute to a more nuanced understanding of the impact of knowledge on inequality and to become aware of their own role in this process. Instead of mainly serving the economy, they need to foster a more complex understanding of knowledge society. This results in rising demands for urban and societal engagement on the part of universities. Today's universities act as local entrepreneurs, engage in school education and public health, and provide technology transfer. They take on civic roles and get involved on a regional level. Under the heading of a "third mission," this new role is emphasized in the context of the knowledge society. Apart from teaching and education (first mission) and research to produce knowledge (second mission), the transfer of knowledge into the society is receiving increased attention (Berghaeuser \& Hoelscher, 2020). During the last years, one can find a shift from a mere technological knowledge transfer into enterprises towards demands for multifaceted engagement in the host city. Knowledge transfer receives a stronger local dimension when universities are asked to link their activities to the local socioeconomic context and thereby take responsibility for urban society.

This change becomes especially obvious in the course of new research formats, such as urban living labs or real-world labs that have incorporated the role of transmitters between research, education, and civil society action into the very heart of their structures (Gerhard \& Marquardt, 2017). Such formats are used to define the collaboration between town and gown, between city and university, in a new way; they are thus becoming increasingly popular across the world. Municipalities, enterprises, universities, and citizens are working together to meet the formidable challenges societies face today. This provides new opportunities for research and learning, but also complicates the relationship. Universities and other educational institutions have to become more self-reflective in this regard, especially when, as they nurture and promote urban growth, they are simultaneously driving some parts of urban society apart. Therefore, the shift from an "urban university" to a "university in urban society" (Addie, 2017)—one that is thus anchored in a city and taking on regional responsibilities while being aware of the host city's needsseems an important step towards preventing new social inequalities in a knowledge society. 


\section{References}

Addie, J.-P. D. (2017). From the urban university to universities in urban society. Regional Studies, 51, 1089-1099. https://doi.org/10.1080/00343404.2016.1224334

Addie, J.-P. D. (2018). Urban(izing) university strategic planning: An analysis of London and New York City. Urban Affairs Review, 55, 1612-1645. https://doi. org/10.1177/1078087417753080

Addie, J.-P. D., Keil, R., \& Olds, K. (2015). Beyond town and gown: Universities, territoriality and the mobilization of new urban structures in Canada. Territory, Politics, Governance, 3, 27-50. https://doi.org/10.1080/21622671.2014.924875

Anheier, H. K., \& Isar, Y. R. (Eds.). (2012). Cities, cultural policy and governance. London: Sage.

Audretsch, D. B. (2014). From the entrepreneurial university to the university for the entrepreneurial society. The Journal of Technology Transfer, 39, 313-321. https://doi.org/10.1007/ s10961-012-9288-1

Barone, C., \& Schizzerotto, A. (2011). Introduction: Career mobility, education, and intergenerational reproduction in five European societies. European Societies, 13, 331-345. https://doi. org/10.1080/14616696.2011.568248

Baumgartner, W. H., \& Rothfuß, E. (2017). Creative inequality in the mid-sized university city: Socio-spatial reflections on the Brazilian rural-urban interface: The case of Cachoeira. In U. Gerhard, M. Hoelscher, \& D. Wilson (Eds.), Inequalities in creative cities: Issues, approaches, comparisons (pp. 217-237). New York: Palgrave-Macmillan.

Baur, C. (2013). Schule, Stadtteil, Bildungschancen: Wie ethnische und soziale Segregation Schüler/-innen mit Migrationshintergrund benachteiligt [School, city district, educational opportunities: How ethnic and social segregation disadvantages pupils with a migration background]. Bielefeld: transcript.

Benneworth, P., Charles, D., \& Madanipour, A. (2010). Building localized interactions between universities and cities through university spatial development. European Planning Studies, 18, 1611-1629. https://doi.org/10.1080/09654313.2010.504345

Berghaeuser, H., \& Hoelscher, M. (2020). Reinventing the third mission of higher education in Germany: Political frameworks and universities' reactions. Tertiary Education and Management, 26, 57-76. https://doi.org/10.1007/s11233-019-09030-3

Bontje, M., \& Musterd, S. (2009). Creative industries, creative class and competitiveness: Expert opinions critically appraised. Geoforum, 40, 843-852. https://doi.org/10.1016/j. geoforum.2009.07.001

Bose, S. (2015). Universities and the redevelopment politics of the neoliberal city. Urban Studies, 52, 2616-2632. https://doi.org/10.1177/0042098014550950

Boterman, W., Musterd, S., Pacchi, C., \& Ranci, C. (2019). School segregation in contemporary cities: Socio-spatial dynamics, institutional context and urban outcomes. Urban Studies, 56, 3055-3073. https://doi.org/10.1177/0042098019868377

Boudon, R. (1974). Education, opportunity and social inequality: Changing prospects in Western society. New York: Wiley.

Breen, R., Luijkx, R., Müller, W., \& Pollak, R. (2009). Nonpersistent inequality in educational attainment: Evidence from eight European countries. American Journal of Sociology, 114, 1475-1521. https://doi.org/10.1086/595951

Bukodi, E., \& Goldthorpe, J. H. (2013). Decomposing 'social origins': The effects of parents' class, status, and education on the educational attainment of their children. European Sociological Review, 29, 1024-1039. https://doi.org/10.1093/esr/jcs079

Burger, K. (2019). The socio-spatial dimension of educational inequality: A comparative European analysis. Studies in Educational Evaluation, 62, 171-186. https://doi.org/10.1016/j. stueduc.2019.03.009

Burstedde, A., \& Werner, D. (2019). Von Abwanderung betroffene Arbeitsmärkte stärken [Strengthening labor markets affected by emigration]. IW-Report, 26. Retrieved from https:// 
www.iwkoeln.de/fileadmin/user_upload/Studien/Report/PDF/2019/IW-Report_2019_ Binnenwanderung.pdf

Candipan, J. (2019). Neighbourhood change and the neighbourhood-school gap. Urban Studies, 56, 3308-3333. https://doi.org/10.1177/0042098018819075

Chatterton, P., \& Goddard, J. (2003). The response of HEIs to regional needs. In R. Rutten, F. Boekema, \& E. Kuypers (Eds.), Economic geography of higher education: Knowledge, infrastructure and learning regions (pp. 19-41). London: Routledge.

Clark, B. (2001). The entrepreneurial university: New foundations for collegiality, autonomy, and achievement. Higher Education Management, 13(2), 9-24.

Combet, B. (2019). The institutional dimension of class-based educational decision-making: Evidence from regional variation in Switzerland. Zeitschrift für Soziologie, 48, 301-320. https://doi.org/10.1515/zfsoz-2019-0021

Delanty, G. (2001). Challenging knowledge: The university in the knowledge society. London, UK: Open University Press.

Egner, B., \& Grabietz, K. J. (2018). In search of determinants for quoted housing rents: Empirical evidence from major German cities. Urban Research \& Practice, 11, 460-477. https://doi. org/10.1080/17535069.2017.1395906

Eurostat. (2020). Database. Education - cities and greater cities [urb_ceduc]. Retrieved from https://ec.europa.eu/eurostat/web/products-datasets/-/urb_ceduc

Evans, G. (2009). Creative cities, creative spaces and urban policy. Urban Studies, 46, 1003-1040. https://doi.org/10.1177/0042098009103853

Florida, R. L. (2002). The rise of the creative class: And how it's transforming work, leisure, community and everyday life. New York: Basic.

Florida, R. L. (2005). Cities and the creative class. New York: Routledge.

Florida, R. L. (2017). The new urban crisis: How our cities are increasing inequality, deepening segregation, and failing the middle class - and what we can do about it. New York: Basic.

Friedmann, J. (1986). The world city hypothesis. Development and Change, 17, 69-83. https://doi. org/10.1111/j.1467-7660.1986.tb00231.x

Fröhlich, K. (2021). Stadtentwicklung in der Wissensgesellschaft: Eine empirische Untersuchung der strategischen Instrumente Reallabor und IBA am Beispiel Heidelberg [Urban development in the knowledge society: An empirical study of the strategic instruments real-world laboratories and IBA using the example of Heidelberg]. Sozial- und Kulturgeographie: Vol. 42. Bielefeld: transcript.

Fröhlich, K., \& Gerhard, U. (2017). Wissensbasierte Stadtentwicklung-ein Erfolgskonzept auch für Nachhaltigkeit? Einblicke in die Entwicklung der Heidelberger Südstadt aus Reallaborperspektive [Knowledge-based urban development-a successful concept also for sustainability? Insights into the development of Heidelberg Südstadt from a real-world laboratory perspective]. Berichte. Geographie und Landeskunde, 91, 13-33.

Gabe, T., Abel, J., Ross, A., \& Stolarick, K. (2012). Knowledge in cities. Urban Studies, 49, 1179-1200. https://doi.org/10.1177/0042098011411949

Gerhard, U., \& Marquardt, E. (2015). The greener, the happier? Urban sustainability in the knowledge city: Policies, programs and practices in the German context. In D. Wilson (Ed.), The politics of urban and regional sustainability: Appraising the concept and process (pp. 65-86). Champaign: Common Grounds.

Gerhard, U., \& Marquardt, E. (2017). Reallabore als innovatives Forschungsformat zur Untersuchung nachhaltiger Stadtentwicklung —eine kritische Reflexion [Real-world laboratories as an innovative research format for investigating sustainable urban development-a critical reflection]. Berichte. Geographie und Landeskunde, 91, 97-111.

Glückler, J., Panitz, R., \& Janzen, K. (2019). Jährliche wirtschaftliche Effekte der Landesuniversitäten in Baden-Württemberg: Studie im Auftrag der Landesrektorenkonferenz Baden-Württemberg [Annual economic effects of the state universities in Baden-Württemberg: Study commissioned by the State Rectors' Conference of Baden-Württemberg]. Heidelberg, Germany: Heidelberg University. https://doi.org/10.11588/heidok.00027338 
Goddard, J., \& Vallance, P. (2011). Universities and regional development. In A. Pike, A. RodríguezPose, \& J. Tomaney (Eds.), Handbook of local and regional development (pp. 425-437). London: Routledge.

Goldthorpe, J. (2003). The myth of education-based meritocracy: Why the theory isn't working. New Economy, 10, 234-239. https://doi.org/10.1046/j.1468-0041.2003.00324.x

Growe, A. (2019). Developing trust in face-to-face interaction of knowledge-intensive business services (KIBS). Regional Studies, 53, 720-730. https://doi.org/10.1080/00343404.2018.1473567

Hadjar, A., \& Becker, R. (2016). Education systems and meritocracy: Social origin, educational and status attainment. In A. Hadjar \& C. Gross (Eds.), Education systems and inequalities: International comparisons (pp. 231-258). Bristol, UK: Policy Press. https://doi.org/10.1332/ policypress/9781447326106.003.0012

Hadjar, A., \& Gross, C. (Eds.). (2016). Education systems and inequalities: International comparisons. Bristol, UK: Policy Press.

Hall, P. (1997). The university and the city. GeoJournal, 41, 301-309. https://doi.org/10.102 3/A:1006806727397

Harmon, C., Oosterbeek, H., \& Walker, I. (2003). The returns to education: Microeconomics. Journal of Economic Surveys, 17, 115-156. https://doi.org/10.1111/1467-6419.00191

Helbig, M., \& Jähnen, S. (2018). Wie brüchig ist die soziale Architektur unserer Städte? Trends und Analysen der Segregation in 74 deutschen Städten [How fragile is the social architecture of our cities? Trends and analyses of segregation in 74 German cities] (Wissenschaftszentrum Berlin für Sozialforschung: Discussion Paper P 2018-001). Retrieved from http://dennymoeller.de/ wp-content/uploads/2018/10/WZB-Segregation.pdf

Herrmann, C. (2020). Urbanität und Egonetzwerke in der Stadt: Eine relationale Perspektive auf die Heidelberger Bahnstadt [Urbanity and ego networks in the city: A relational perspective on the Heidelberg district Bahnstadt]. Wiesbaden: Springer VS.

Heynen, N., Aiello, D., Keegan, C., \& Luke, N. (2018). The enduring struggle for social justice and the city. Annals of the American Association of Geographers, 108, 301-316. https://doi.org/1 $0.1080 / 24694452.2017 .1419414$

Hillmert, S. (2011). Occupational mobility and developments of inequality along the life course: The German case. European Societies, 13, 401-423. https://doi.org/10.1080/1461669 6.2011 .568263

Hoelscher, M. (2012). Universities and higher learning. In H. K. Anheier \& M. Juergensmeyer (Eds.), Encyclopedia of global studies (pp. 1713-1718). London: Sage.

Hoelscher, M., \& Harris-Huemmert, S. (2019). Place and space in higher education: Past, present and future visions of physical and virtual realities. Beiträge zur Hochschulforschung, $41(1), 8-23$.

Internationale Bauausstellung Heidelberg. (n.d.). Retrieved from https://iba.heidelberg.de/en

Jöns, H., \& Hoyler, M. (2013). Global geographies of higher education: The perspective of world university rankings. Geoforum, 46, 45-59. https://doi.org/10.1016/j.geoforum.2012.12.014

Knight, R. V. (1995). Knowledge-based development: Policy and planning implications for cities. Urban Studies, 32, 225-260. https://doi.org/10.1080/00420989550013068

Kroll, H., Dornbusch, F., \& Schnabl, E. (2016). Universities' regional involvement in Germany: How academics' objectives and opportunity shape choices of activity. Regional Studies, 50, 1595-1610. https://doi.org/10.1080/00343404.2015.1051016

Kujath, H. J. (2012). Reurbanisierung des Wissens: Zur Herausbildung von Metropolregionen unter dem Einfluss der Wissensökonomie [Reurbanization of knowledge: On the development of metropolitan regions under the influence of the knowledge economy]. In K. Brake \& G. Herfert (Eds.), Reurbanisierung: Materialität und Diskurs in Deutschland (pp. 216-238). Wiesbaden: Springer VS. https://doi.org/10.1007/978-3-531-94211-7

Kunzmann, K. R. (2004). Culture, creativity and spatial planning. The Town Planning Review, 75, 383-404. Retrieved from https://www.jstor.org/stable/40112620

Landry, C. (2008). The creative city: A toolkit for urban innovators. London: Earthscan. 
Lazzeroni, M., \& Piccaluga, A. (2015). Beyond 'Town and Gown': The role of the university in small and medium-sized cities. Industry \& Higher Education, 29, 11-23. https://doi. org/10.5367/ihe. 2015.0241

Lipman, P. (2002). Making the global city, making inequality: The political economy and cultural politics of Chicago school policy. American Educational Research Journal, 39, 379-419. https://doi.org/10.3102/00028312039002379

Lipman, P. (2011). The new political economy of urban education: Neoliberalism, race, and the right to the city. New York: Routledge. https://doi.org/10.1111/j.1548-1492.2012.01183.x

Liu, C. (2019). The tensions of university - city relations in the knowledge society. Education and Urban Society, 51, 120-143. https://doi.org/10.1177/0013124517727582

Lucas, S. R., \& Byrne, D. (2017). Effectively maintained inequality in education: An introduction. American Behavioral Scientist, 61, 3-7. https://doi.org/10.1177/0002764216682992

Maasen, P., Andreadakis, Z., Gulbrandsen, M., \& Stensaker, B. (2019). The place of universities in society. Hamburg: Körber-Stiftung.

Marquardt, E. (2019). Hochschule und Stadt als Partner in Reallaboren: Neue Wege für ein konstruktives Miteinander [University and city as partners in real-world laboratories: New ways for a constructive cooperation]. Beiträge zur Hochschulforschung, 41(1), 108-123.

Matthiesen, U., \& Mahnken, G. (Eds.). (2009). Das Wissen der Städte: Neue stadtregionale Entwicklungsdynamiken im Kontext von Wissen, Milieus und Governance [The knowledge of cities: New urban-regional development dynamics in the context of knowledge, milieus and governance]. Wiesbaden: VS Verlag für Sozialwissenschaften.

McDowell, L., \& Dyson, J. (2011). The other side of the knowledge economy: 'Reproductive' employment and affective labours in Oxford. Environment and Planning A, 43, 2186-2201. https://doi.org/10.1068/a43591

Merkel, J. (2012). Kreative Milieus [Creative milieus]. In F. Eckardt (Ed.), Handbuch Stadtsoziologie (pp. 689-710). Wiesbaden: VS Verlag für Sozialwissenschaften. https://doi. org/10.1007/978-3-531-94112-7_30

Meusburger, P. (2009). Milieus of creativity: The role of places, environments, and spatial contexts. In P. Meusburger, J. Funke, \& E. Wunder (Eds.), Milieus of creativity: An interdisciplinary approach to spatiality of creativity (pp. 97-153). Knowledge and Space: Vol. 2. Dordrecht: Springer. https://doi.org/10.1007/978-1-4020-9877-2_7

Meusburger, P. (2016). „Wissenschaftsstadt Heidelberg“: Analysen und Strategien ['Science City Heidelberg': Analyses and strategies]. Heidelberg: Stadt Heidelberg. Retrieved from https://www.heidelberg.de/site/Heidelberg_ROOT/get/params_E-1858158413/813575/ Strategiepapier_Wissenschaftsstadt_2016-10-10_Dr_Peter_Meusburger.pdf

Oberti, M., \& Savina, Y. (2019). Urban and school segregation in Paris: The complexity of contextual effects on school achievement: The case of middle schools in the Paris metropolitan area. Urban studies, 56, 3117-3142. https://doi.org/10.1177/0042098018811733

OECD. (2016). PISA 2015 Results (Vol. 1): Excellence and equity in education. Paris: PISA, OECD. https://doi.org/10.1787/9789264266490-en

Oeltjen, M., \& Windzio, M. (2019). Räumliche Segregation durch ungleiche Bildungskontexte? Wahrgenommene Nachbarschaftsmerkmale und Umzüge von Familien [Spatial segregation due to unequal educational contexts? Perceived neighborhood characteristics and moving of families]. Kölner Zeitschrift für Soziologie und Sozialpsychologie, 71, 651-675. https://doi. org/10.1007/s11577-019-00641-7

Owens, A., \& Candipan, J. (2019). Social and spatial inequalities of educational opportunity: A portrait of schools serving high- and low-income neighbourhoods in US metropolitan areas. Urban Studies, 56, 3178-3197. https://doi.org/10.1177/0042098018815049

Pollak, R., \& Müller, W. (2018). Education as an equalizing force: How have declining educational inequality and educational expansion contributed to more social fluidity in Germany? (Mannheimer Zentrum für Europäische Sozialforschung, Working Paper 171). Mannheim: MZES. Retrieved from https://www.mzes.uni-mannheim.de/publications/wp/wp-171.pdf 
Rausch, S., \& Negrey, C. (2006). Does the creative engine run? A consideration of the effect of creative class on economic strength and growth. Journal of Urban Affairs, 28, 473-489. https:// doi.org/10.1111/j.1467-9906.2006.00310.x

Sassen, S. (2001). The global city (2nd ed.). Princeton, NJ: Princeton University Press. (Original work published 1991)

Scott, A. J. (2006). Creative cities: Conceptual issues and policy questions. Journal of Urban Affairs, 28, 1-17. https://doi.org/10.1111/j.0735-2166.2006.00256.x

Siegfried, J. J., Sanderson, A. R., \& McHenry, P. (2007). The economic impact of colleges and universities. Economics of Education Review, 26, 546-558. https://doi.org/10.1016/j. econedurev.2006.07.010

Smith, D. P. (2004). 'Studentification': The gentrification factory? In R. Atkinson \& G. Bridge, (Eds.), Gentrification in a global context: The new urban colonialism (pp. 73-90). Abingdon: Routledge.

Stadt Heidelberg. (2011). Mietspiegel 2011: Mietspiegel der Stadt Heidelberg [Rent index of Heidelberg 2011]. Heidelberg: Stadt Heidelberg, Amt für Stadtentwicklung und Statistik. Retrieved from https://docplayer.org/61772916-Mietspiegel-2011-mietspiegel-der-stadtheidelberg.html

Stadt Heidelberg. (2018a). Bericht zur sozialen Lage in Heidelberg 2018 [Social situation report in Heidelberg, 2018]. Heidelberg: Stadt Heidelberg, Amt für Stadtentwicklung und Statistik. Retrieved from https://www.heidelberg.de/site/Heidelberg_ROOT/get/params_E506702557/1217489/01_Bericht_zur_Soziale_Lage_in_Heidelberg_2018\%20\%282\%29.pdf

Stadt Heidelberg. (2018b). Heidelberg-Studie 2018: Leben und Wohnen [Heidelberg study 2018: Living and housing]. Heidelberg: Stadt Heidelberg, Amt für Stadtentwicklung und Statistik. Retrieved from https://www.heidelberg.de/site/Heidelberg_ROOT/get/documents_E1763942434/heidelberg/Objektdatenbank/12/PDF/12_pdf_Heidelberg-Studie\%202018.pdf

Stadt Heidelberg. (2019). Mietspiegel 2019 der Stadt Heidelberg [Rent index of Heidelberg 2019]. Heidelberg: Stadt Heidelberg, Amt für Stadtentwicklung und Statistik. Retrieved from https://www.heidelberg.de/site/Heidelberg_ROOT/get/documents_E-1749778114/heidelberg/ Objektdatenbank/12/PDF/12_pdf_Mietspiegel_2019.pdf

Sörlin, S., \& Vessuri, H. (Eds.). (2007). Knowledge society vs. knowledge economy: Knowledge, power, and politics. New York: Palgrave Macmillan.

Stehr, N., \& Meja, V. (Eds.). (1984). Society and knowledge: Contemporary perspectives in the sociology of knowledge and science. New Brunswick: Transaction.

Storper, M., \& Scott, A. J. (2009). Rethinking human capital, creativity and urban growth. Journal of Economic Geography, 9, 147-167. https://doi.org/10.1093/jeg/lbn052

van Winden, W., van den Berg, L., \& Pol, P. (2007). European cities in the knowledge economy: Towards a typology. Urban Studies, 44, 525-549. https://doi.org/10.1080/00420980601131886

Walker, R. A. (2018). Pictures of a gone city: Tech and the dark side of prosperity in the San Francisco Bay Area. Oakland: PM.

Warnecke, C. (2018). New survey data on the role of universities in the German regional innovation system. Journal of Economics and Statistics, 238, 601-608. https://doi.org/10.1515/ jbnst-2017-0159

Weiss, F., \& Schindler, S. (2017). EMI in Germany: Qualitative differentiation in a tracked education system. American Behavioral Scientist, 61, 74-93. https://doi.org/10.1177/0002764216682811

Wilson, D. (2018). Chicago's redevelopment machine \& blues clubs. Cham: Palgrave-Macmillan. https://doi.org/10.1007/978-3-319-70818-8

Woessmann, L. (2016). The economic case for education. Education Economics, 24, 3-32. https:// doi.org/10.1080/09645292.2015.1059801

Yigitcanlar, T. (2009). Planning for knowledge-based urban development: Global perspectives. Journal of Knowledge Management, 13, 228-242. https://doi.org/10.1108/13673270910988079

Zangger, C. (2018). Bringing space into the equation: Modelling the social and spatial interdependence of neighborhood effects on educational outcomes. Research in Social Stratification and Mobility, 55, 63-74. https://doi.org/10.1016/j.rssm.2018.03.007

Zukin, S. (2011). Naked city: The death and life of authentic urban places. New York, NY: Oxford University Press. 
Open Access This chapter is licensed under the terms of the Creative Commons Attribution 4.0 International License (http://creativecommons.org/licenses/by/4.0/), which permits use, sharing, adaptation, distribution and reproduction in any medium or format, as long as you give appropriate credit to the original author(s) and the source, provide a link to the Creative Commons license and indicate if changes were made.

The images or other third party material in this chapter are included in the chapter's Creative Commons license, unless indicated otherwise in a credit line to the material. If material is not included in the chapter's Creative Commons license and your intended use is not permitted by statutory regulation or exceeds the permitted use, you will need to obtain permission directly from the copyright holder.

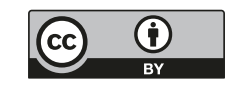

